\title{
A STUDY OF THE RELATIVE BINDING CAPACITY OF PLASMA PROTEINS, INTACT HUMAN RED CELLS, AND HUMAN RED CELL STROMA FOR RADIOACTIVE I-131 LABELED L-THYROXINE
}

\author{
By K. R. CRISPELL AND JOSEPH COLEMAN 1 \\ (From the Department of Internal Medicine, University of Virginia School of Medicine, \\ Charlottesville, $V$ a.)
}

(Submitted for publication September 26, 1955 ; accepted January 16, 1956)

Previous studies (1-3) have demonstrated the binding properties of serum protein for L-thyroxine and to a lesser extent for L-triiodothyronine. Previous studies from our laboratory (4) have shown that human red cells also have a binding or assimilating capacity for L-thyroxine and L-triiodothyronine.

The purpose of this paper is to present further information on the binding of L-thyroxine and L-triiodothyronine by human red cells. We will also present studies on the binding of these two substances by human red cell stroma, and the relative binding capacity for plasma proteins and human intact red cells.

\section{METHODS AND MATERIALS}

Whole blood, drawn with a heparinized syringe from healthy volunteers, was centrifuged in $15-\mathrm{ml}$. test tubes at $1500 \mathrm{rpm}$ for 20 minutes. (The centrifuge radius was $18 \mathrm{~cm}$. and the radial acceleration was $453 \mathrm{~g}$ 's.) The plasma was drawn off and normal saline solution added to the tubes containing the packed red cells. These were then gently mixed and recentrifuged as before. The supernatant was again drawn off and the wash procedure repeated once more, the packed cells remaining being termed "washed red cells." In each washing sufficient normal saline solution was added to fill a $15 \times 125$ $\mathrm{mm}$. test tube containing about $6 \mathrm{ml}$. of packed cells.

Test tubes containing $2 \mathrm{ml}$. of the radioactive standard, I-131-labeled sodium L-thyroxine or I-131-labeled sodium L-triiodothyronine, were set up and the amount of radioactivity of each in counts per minutes was determined in a well type (Nuclear $R$ ) scintillation counter. The standard was prepared by diluting $1 \mathrm{ml}$. of the radioactive L-thyroxine or L-triiodothyronine ${ }^{2}$ 1:1000 with normal saline solution. This preparation is dissolved in 50 per cent propylene glycol. Aliquots of this dilution were then diluted from 2 to 100 times for the final standard depending on the amount of decay. This resulted

1 S. E. Massengill Fellowship for student research during summer of 1955.

2 Obtained from Abbott Laboratories, Oak Ridge, Tennessee. in there being between $1.0 \times 10^{-4}$ to $5.0 \times 10^{-6}$ micrograms of hormone in $2 \mathrm{ml}$. of the standard. Two $\mathrm{ml}$. of the washed cells were then added to each tube containing the precounted standard. These were gently mixed and incubated for 30 minutes at $37^{\circ} \mathrm{C}$. After the incubation, normal saline solution was added to the tubes, the tubes gently mixed, centrifuged, and the supernatant drawn off. This procedure was repeated once more and the remaining $2 \mathrm{ml}$. of packed cells counted in a well counter. This counting rate was expressed as a percentage of the counting rate of the corresponding $2 \mathrm{ml}$. of radioactive standard. This percentage was termed the percentage uptake by the red cell.

After this procedure, $2 \mathrm{ml}$. of fresh human plasma was added to the same $2 \mathrm{ml}$. of red cells used for the uptake; the tubes gently mixed and incubated for 30 minutes at $37^{\circ} \mathrm{C}$. The mixture was then centrifuged and the plasma drawn off. Following this the cells were washed twice with normal saline solution as after the uptake procedure. The counting rate at the end of this incubation and washing was then expressed as a percentage of the counting rate at the end of the uptake study. This was the percentage of the labeled material originally with the cell that remained with it after incubation with fresh plasma. The procedure was then repeated once more with another $2 \mathrm{ml}$. of fresh plasma to determine if further radioactivity could be removed from the cells. The variation in recovery of radioactivity as a function of the amount of plasma added was determined by preparing a series of eight tubes containing 0.0 to $0.50 \mathrm{ml}$. of plasma and made up to a volume of $2 \mathrm{ml}$. with normal saline solution. The contents of these tubes were then added to the cells remaining from the uptake study, gently mixed, incubated, and the washings repeated as above. The percentage of the radioactivity remaining with the red cells subtracted from one hundred gave the percentage of radioactivity with the cell recoverable by the plasma-saline mixtures.

Varying amounts of stable L-thyroxine were dissolved in $0.02 \mathrm{M} \mathrm{NaOH}$ solution so that each $0.1 \mathrm{ml}$. of the final solutions would contain the following micrograms of L-thyroxine: $2.5,5,10,15,20,30,50$ and 100 . Human fresh plasma $(1.0 \mathrm{ml}$.) was then incubated with $0.1 \mathrm{ml}$. of each of the above solutions for 30 minutes at $37^{\circ} \mathrm{C}$. Then $0.1 \mathrm{ml}$. of this "incubated" plasma was added to the radioactive L-thyroxine and L-triiodothyronine and allowed to stand for 15 minutes. Two $\mathrm{ml}$. of 
washed human red cells were added to each tube and the uptake by the red cells of the radioactive labeled material determined as described previously (4). A control study was also carried out using $0.1 \mathrm{ml}$. of $0.02 \mathrm{M}$ $\mathrm{NaOH}$ solution.

The uptake by twenty-one-day old refrigerated human washed red cells of radioactive labeled L-thyroxine and L-triiodothyronine was also carried out.

Human red cells were washed with a $0.02 \mathrm{M}$ sodium fluoride solution allowing the sodium fluoride solution to remain in contact with the red cells for at least 30 minutes before centrifugation. The uptake by these cells for radioactive I-131 labeled L-thyroxine and L-triiodothyronine was determined in the usual manner.

The uptake by the human red cells of radioactive labeled L-thyroxine and L-triiodothyronine was carried out at the following temperatures: $0^{\circ}, 5^{\circ}, 15^{\circ}, 25^{\circ}, 30^{\circ}$, and $37^{\circ}$ Centigrade.

Red cell stroma was prepared according to the method of Tishkoff, Robscheit-Robbins, and Whipple (5) who used a modification of the method of Ballentine (6). The uptake and recovery for the stroma was done much like that of the cells. Two $\mathrm{ml}$. of the stroma suspension was suspended in $2 \mathrm{ml}$. of previously counted radioactive standard and incubated for 30 minutes at $37^{\circ} \mathrm{C}$. In the case where human fresh plasma was added it was simply added to the radioactive standard solutions and allowed to stand for 15 minutes at $37^{\circ} \mathrm{C}$ before the stroma was added and incubated. After incubation the stroma was then washed twice with normal saline solution as in the cell study. Applicator sticks were used to resuspend the stroma after each centrifugation. This introduces a

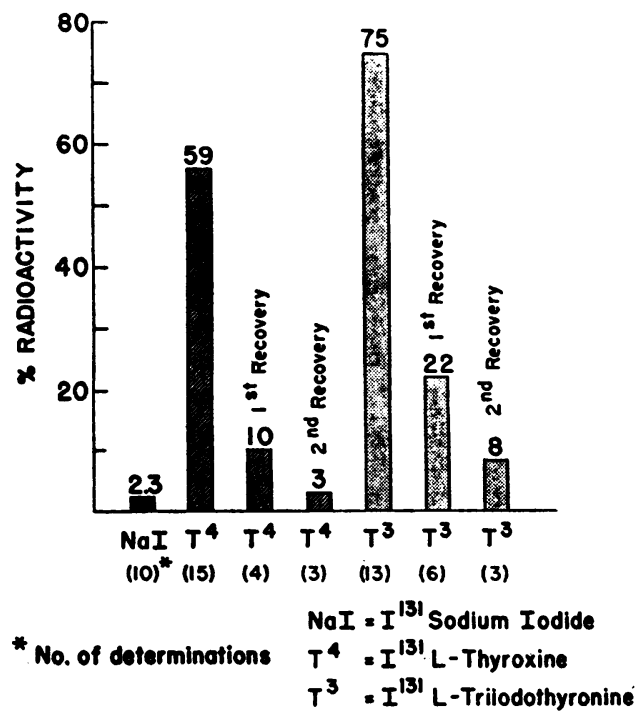

Fig. 1. The Uptake by Human Washed Red Cells of Radionctive I-131 L-Thyroxine, L-Triodothyronine, Sodium Iodide and the Per Cent of Radionctivity Remaining with the Red Cell after the ReCOVEry of the Radioactive Label by Successive INCUbations with Fresh Human Plasma

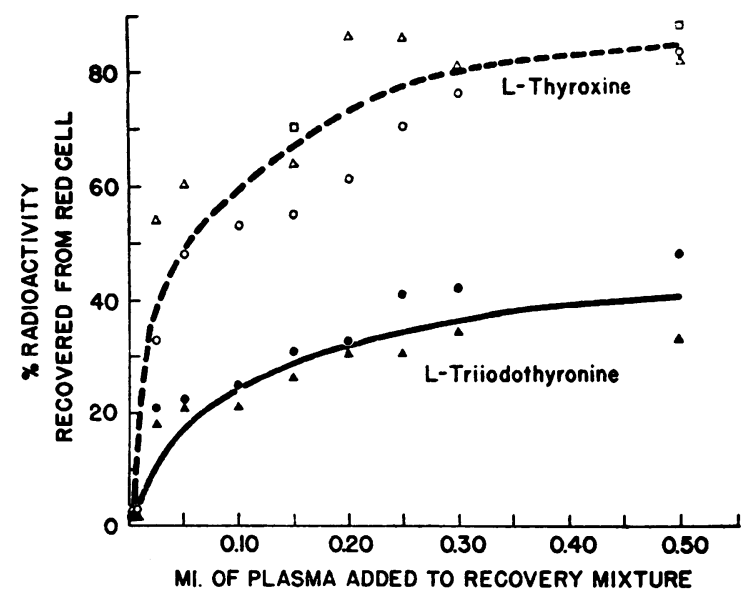

Fig. 2. The Recovery of Radioactive Label from Human Washed Red Cells by Fresh Human PlasmaSaline Mixtures

negligible error as no radioactivity remained with the applicator. The stroma was then counted after the last centrifugation and this expressed as the per cent uptake as in the cell study.

Recovery was done as in the cell study by the resuspension of the stroma (used for the uptake studies) in 2 $\mathrm{ml}$. of fresh human plasma. Again applicator sticks had to be used to suspend the stroma. The recovery suspensions were incubated for 30 minutes at $37^{\circ} \mathrm{C}$, washed twice as above, and recounted. The recovery was expressed as in the red cell study as a percentage of the count with the stroma at the end of the uptake study.

\section{RESULTS}

The average uptake by the washed human red cells of radioactive labeled L-thyroxine was 59 per cent (range 45 to 66 per cent) and for L-triiodothyronine was 75 per cent (range 68 to 80 per cent). It is to be emphasized again that by uptake is meant the per cent of radioactivity remaining with the red cells which cannot be removed by washing with normal saline. After incubation of the red cells (which have been used in the uptake study) with fresh human plasma for 30 minutes at $37^{\circ} \mathrm{C}$ all but 10 per cent (range 8 to 12 per cent) of radioactivity can be removed from the cells that had been previously incubated with radioactive L-thyroxine and all but 22 per cent (range 18 to 26 per cent) of the radioactivity from the cells previously incubated with radioactive L-triiodothyronine. Further incubation with fresh human plasma reduces the residual radioactivity to 3 per cent (range 2 to 6 per cent) for 
the L-thyroxine incubated cells and to 8 per cent for L-triiodothyronine incubated cells. The recovery bars in Figure 1 indicate the percentage of previously retained radioactivity which now remains with the cells after one or two incubations with fresh human plasma (Figure 1).

The amount of radioactivity recovered from the tagged cells was increased as the amount of human fresh plasma with which they were incubated was increased from 0 to $0.5 \mathrm{ml}$. Human fresh plasma was more effective in removing the radioactive tag from the cells incubated with radioactive L-thyroxine than from those cells incubated with L-triiodothyronine (Figure 2). Normal saline solution was again ineffective in removing the radioactive tag from the incubated cells.

The findings using plasma incubated with stable thyroxine are plotted in Figure 3 along with the $\mathrm{NaOH}$ controls in which $0.10 \mathrm{ml}$. of $0.02 \mathrm{M}$ $\mathrm{NaOH}$ was added per ml. of plasma, $0.10 \mathrm{ml}$. of this mixture being added to the uptake medium. The uptake of both I-131 sodium L-thyroxine and I-131 sodium triiodothyronine increases rapidly with previous incubation of the plasma with stable thyroxine. The L-triiodothyronine reached a plateau more rapidly ( 5 or $10 \mu \mathrm{g}$. per $\mathrm{ml}$.) and at a higher level ( 53 per cent uptake) than the L-thyroxine (30 to $35 \mu \mathrm{g}$. per $\mathrm{ml}$. and $30 \mathrm{per}$ cent uptake).

The sodium fluoride treated cells and the 21day-old refrigerated cells demonstrate the same uptake for the two compounds as do normal cells

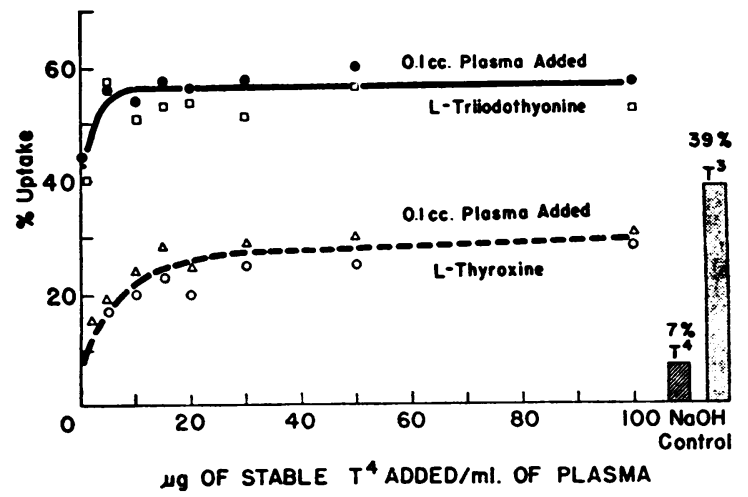

Fig. 3. The Effect on the Uptake of Radioactive I-131 L-Thyroxine AND L-Triodothyronine by $\mathrm{HU}$ man Washed Red Cells Produced by the Addition of Fresh Human Plasma Previously Incubated with Stable L-Thyroxine

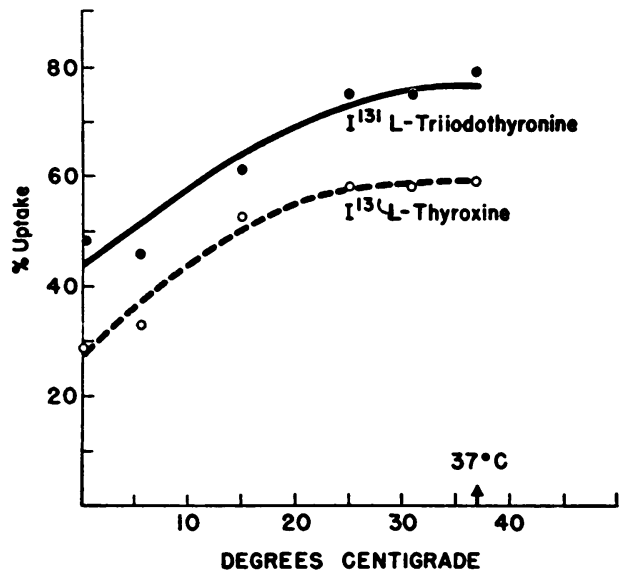

Fig. 4. The Effect of Cold on the Uptake of Radionctive I-131 L-Thyroxine and L-Triodothyronine by Washed Human Red Cells

provided fresh matched plasma is used with the old cells. Cold inhibits the uptake of both compounds by the cells. This decreases sharply as the temperature goes below $20^{\circ} \mathrm{C}$ (Figure 4).

Human red cell stroma exhibits much the same uptake and recovery characteristics that the intact cells do. Washed stroma takes up an average of 72 per cent (range 70 to 73 per cent) of the L-thyroxine in the medium and 76 per cent (range 75 to 78 per cent) of the L-triiodothyronine. NaI uptake is only 10 per cent. The addition of a small amount of plasma to the medium reduces the uptake greatly, $0.50 \mathrm{ml}$. reducing it to 15 per cent in the case of L-thyroxine. Incubation with fresh plasma recovers all but 13 per cent (range 11 to 14 per cent) of the L-thyroxine and 25 per cent (range 24 to 28 per cent) of the L-triiodothyronine originally associated with the stroma. Again saline alone is ineffective. The uptake and recovery for the stroma is presented in Figure 5.

\section{DISCUSSION}

Deiss, Albright, and Larson (1-3) have demonstrated the binding properties of serum proteins for L-thyroxine and L-triiodothyronine by paper radioelectrophoresis. They have shown by both in vivo and in vitro experiments that both L-thyroxine and L-triiodothyronine associate with a serum protein just ahead of the alpha-2 globulin zone which has been termed thyroxine-bindingglobulin or TBG. L-thyroxine is also capable of 


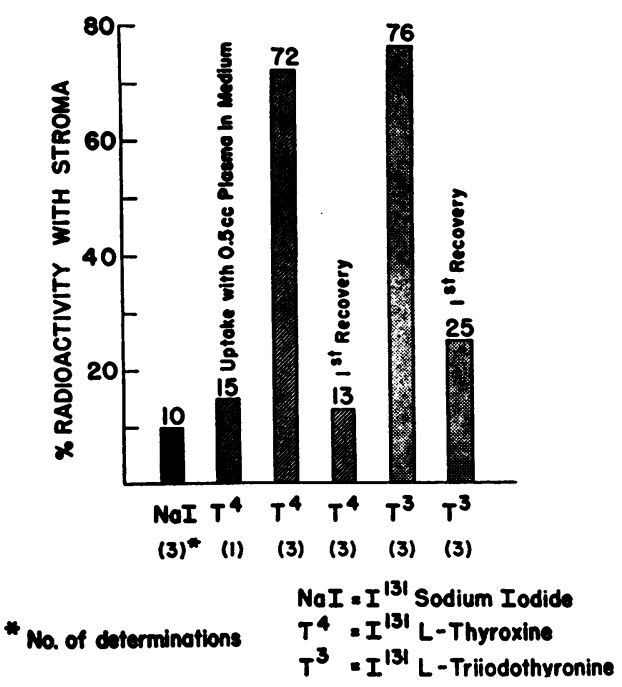

Fig. 5. The Uptake of Radioactive I-131 L-Thyroxine and L-Tritodothyronine by Red Cell Stroma, the Effect of Fresh Human Plasma on the Uptake of L-Thyroxine, and the Amount of Radioactivity Remaining with the Stroma after the Recovery of the Radionctive Material by Fresh Human Plasma

displacing triiodothyronine from this protein indicating that the protein has a greater affinity for the tetraiodinated compound. This has also been demonstrated by Robbins and Rall (7). Furthermore, when TBG has previously been saturated with hormone, triiodothyronine trails off over the electrophoretic pattern with no quantitative relationship to protein indicating that it is not specifically bound by other serum proteins, while L-thyroxine is shown to associate with albumin. These workers feel this may account for a greater diffusibility of triiodothyronine and hence its more rapid disappearance from the serum.

Previous studies from our laboratory have shown that human red cells also have a binding or assimilating capacity for L-thyroxine and L-triiodothyronine (4). In this case the affinity of the intact red cells seemed to be greater for the triiodinated compound. Human plasma reduces the uptake of both compounds greatly; however, it is more effective in reducing the uptake of L-thyroxine than it is of L-triiodothyronine. This may also explain the apparent greater uptake of the L-triiodothyronine. Hamolsky (8) has presented evidence that the "uptake" by human red cells of L-triiodothyronine from plasma was greater than that of L-thyroxine. He also dem- onstrated that there was a greater "uptake" of L-triiodothyronine by human red cells from hyperthyroid plasma than from euthyroid plasma (8). In the present study the fact that fluoride ion or 21 days of cold storage have no effect on the cell uptake is evidence against this uptake being directly dependent on cell respiration although the red cell is considerably more inactive metabolically than other body cells. Christensen, Riggs, and Ray (9) have found difficulty in inhibiting the "uptake" of amino acids by red cells with enzyme poisons. Further support, however, that in the case of the iodinated amino acids, L-thyroxine and L-triiodothyronine, the red cell uptake is not directly dependent on respiration is provided by the fact that red cell stroma in which all respiratory and enzymatic processes are destroyed demonstrates much the same phenomenon.

The fact that fresh plasma mixtures are successful in recovering both the labeled hormones from the cells and the stroma is further evidence that this uptake is an equilibrium phenomenon between receptors for the hormones on the plasma proteins and receptors on the red cell, perhaps on the "red cell fixed framework" or stroma which is thought to consist of a complex structure of protein and lipid molecules. Cold inhibition of the uptake is compatible with an equilibrium phenomenon.

Evidence has been presented by Hoch and Lipmann (10) in experiments with liver mitochondria (rat and hampster) which indicates a binding capacity of cellular structures for thyroxine and triiodothyronine which is not immediately related to its metabolic activity. They have shown that while 80 to 90 per cent of the added hormone in a medium surrounding the mitochondria will attach itself to the mitochondria, there was no correlation between this absorption and the metabolic effect of the hormones as they measured it.

In the studies reported here the smaller cellular uptake of L-thyroxine and the more efficient recovery of it by plasma as compared to L-triiodothyronine is perhaps explained on the more avid binding by TBG and albumin of the thyroxine. One will note that the uptake by the stroma of the two compounds is very similar. The recovery of radioactivity from the stroma by plasma was greater for thyroxine (Figure 5). The washed 
cells may still have a small component of plasma with them which would explain the decreased uptake of L-thyroxine as compared to uptake by stroma.

We are aware of the fact that we are assuming that the radioactivity recovered from the tagged red cells by the fresh plasma is still attached to the original label, the thyroid hormones. It is not in the form of inorganic iodide or it would have been washed away from the cell by the saline washings. Studies are now in progress to show that the recovered radioactivity is still attached to the original label.

Further evidence for the role played in the uptake by the binding capacities of plasma for the two hormones is demonstrated when the plasma added to the medium is previously incubated with stable thyroxine. The increase in uptake by the cell of both labeled L-thyroxine and L-triiodothyronine when the plasma has been previously incubated with small amounts of stable thyroxine may possibly be explained on the basis of saturation of receptors on the plasma proteins by the stable thyroxine. The fact that triiodothyronine reaches its maximum uptake much more rapidly than thyroxine can be explained on the basis of it being necessary to bind fewer plasma receptors (namely TBG alone) before triiodothyronine becomes fairly "unbound" to plasma protein. In the case of tetraiodothyronine (thyroxine) it may be necessary to saturate some albumin receptors also.

The presence of human fresh plasma inhibits the uptake by the intact human red cell of radioactive L-thyroxine to a greater degree than it does radioactive L-triiodothyronine (4). This could mean a greater binding capacity of the plasma for L-thyroxine or a greater binding capacity or uptake capacity by the intact red cell for triiodothyronine. The fact that the uptake or binding by the human red cell stroma is approximately equal (Figure 5) suggests that the above results are due to a greater binding capacity by human plasma for L-thyroxine. This is further substantiated by the fact that it is possible to remove approximately twice as much L-thyroxine as L-triiodothyronine from human red cell stroma using human fresh plasma (Figure 5).

As stated previously Hoch and Lipmann (10) presented data showing that there was no correlation between metabolic effects and the amount of hormone absorbed by the mitochondria. They also emphasize that activity of the hormone depends upon ability to permeate the cell wall, and suggest that triiodothyronine may be more active because of greater permeability of the cell wall. A second factor might be that the hormone is unavailable due to binding by plasma protein. Our studies suggest that thyroxine would be less available because of the strong binding properties of plasma for this tetra-iodinated compound compared to the tri-iodinated compound.

It should be emphasized that these in vitro studies with human erythrocytes and thyroid hormones may have no in vivo counterpart. The amount of thyroxine found in the red cell from in vivo studies appears to be negligible (11). Studies are in progress using other types of cells to study the binding phenomenon of thyroid hormones.

\section{CONCLUSIONS}

1. The uptake or binding by the human red cell of radioactive I-131 labeled L-thyroxine and L-triiodothyronine is not inhibited by the fluoride ion or storage of the cells for twenty-one days but is inhibited by cold.

2. Human red cell stroma was also shown to take up or bind radioactive I-131 labeled L-thyroxine and L-triiodothyronine.

3. The uptake or binding of the thyroid hormones by human erythrocytes, human erythrocyte stroma, and human plasma appears to be a physical chemical phenomenon not directly dependent on enzymatic processes of red cell respiration.

4. The greater binding capacity of human plasma for L-thyroxine as compared to L-triiodothyronine was again demonstrated.

\section{REFERENCES}

1. Deiss, W. P., Albright, E. C., and Larson, F. C., A study of the nature of the circulating thyroid hormone in euthyroid and hyperthyroid subjects by use of paper electrophoresis. J. Clin. Invest., 1952, 31,1000 .

2. Albright, E. C., Larson, F. C., and Deiss, W. P., Thyroxine binding capacity of serum alpha globulin in hypothyroid, euthyroid, and hyperthyroid subjects. J. Clin. Invest., 1955, 34, 44.

3. Deiss, W. P., Albright, E. C., and Larson, F. C., Comparison of in vitro serum protein binding of 
thyroxine and triiodothyronine. Proc. Soc. Exper. Biol. \& Med., 1953, 84, 513.

4. Crispell, K. R., Kahana, S., and Hyer, H., The effect of plasma on the in vitro uptake or binding by human red cells of radioactive I-131 labeled L-thyroxine and L-triiodothyronine. J. Clin. Invest., 1956, 35, 121.

5. Tishkoff, G. H., Robscheit-Robbins, F. S., and Whipple, G. H., Red cell stroma in dogs. Variations in the stroma protein and lipid fractions related to experimental conditions. Blood, 1953, 8, 459.

6. Ballentine, R., Stromatin. J. Cell. \& Comp. Physiol., 1944, 23, 21.

7. Robbins, J., and Rall, J. E., Effects of triiodothyronine and other thyroxine analogues on thyroxine- binding in human serum. J. Clin. Invest., 1955, 34, 1331.

8. Hamolsky, M. W., The plasma protein-thyroid hormone complex in thyrotoxicosis vs. euthyroidism in man. J. Clin. Invest., 1955, 34, 914 (abstract).

9. Christensen, H. N., Riggs, T. R., and Ray, N. E., Concentrative uptake of amino acids by erythrocytes in vitro. J. Biol. Chem., 1952, 194, 41.

10. Hoch, F. L., and Lipmann, F., The uncoupling of respiration and phosphorylation by thyroid hormones. Proc. Nat. Acad. Sc., 1954, 40, 909.

11. Van Arsdel, P., Jr., Hogness, J. R., Williams, R. H., and Elgee, N., Comparative distribution and fate of I-131 labeled thyroxine and triiodothyronine. Endocrinology, 1954, 55, 332. 